\begin{abstract}
The movements of maturing Pacific salmon (Oncorhynchus spp.) from marine waters into rivers pose challenges for their physiology, especially in basins affected by human structures and increasing temperatures. This study determined the thermal regimes experienced by maturing Chinook salmon (O. tshawytscha) entering the Lake Washington basin in western Washington through navigational locks and a ship canal and migrating through the lake to spawning grounds. Chinook salmon entered in mid-summer, when temperatures were warmest, but often moved back into the cool, marine waters of Puget Sound before travelling quickly through the ship canal and into Lake Washington. In Lake Washington, they swam above and below the thermocline and made little use of the available thermal refuge in deep water before ascending rivers to spawn. The migration timing and tactics of Chinook salmon indicate a greater tolerance for warm water than that of sympatric sockeye salmon (O. nerka, documented in an independent study), but in each species the ability to exploit thermal refuges may be essential for their survival in the face of the increasing temperatures seen in this basin in the past decades and those that are likely to continue rising in the future.
\end{abstract}

Manuscript submitted 24 October 2018. Manuscript accepted 22 August 2019. Fish. Bull. 117:258-271 (2019).

Online publication date: 6 September 2019. doi: 10.7755/FB.117.3.12

The views and opinions expressed or implied in this article are those of the author (or authors) and do not necessarily reflect the position of the National Marine Fisheries Service, NOAA.

\title{
Behavioral thermoregulation by adult Chinook salmon (Oncorhynchus tshawytscha) in estuary and freshwater habitats prior to spawning
}

\author{
Frederick A. Goetz (contact author) ${ }^{1}$ \\ Thomas P. Quinn² \\ Email address for contact author: fred.goetz@usace.army.mil \\ ${ }^{1}$ Seattle District \\ U.S. Army Corps of Engineers \\ P.O. Box 3755 \\ Seattle, Washington 98124-3755 \\ ${ }^{2}$ School of Aquatic and Fishery Sciences \\ University of Washington \\ Box 355020 \\ Seattle, Washington 98195
}

Most fish species live entirely in fresh or salt water, and only a small fraction, from many different evolutionary lineages, migrates regularly between these environments (McDowall, 1988). These diadromous fish species always experience a decrease in salinity and temperature changes when entering fresh water. In the summer and early fall at higher latitudes $\left(>40^{\circ} \mathrm{N}\right)$, the marine waters are typically cooler than the rivers, but the reverse may be the case in winter. Estuaries are the transition zone for this shift between marine and riverine habitats, affording intermediate conditions of salinity and temperature. However, estuaries and their associated waterways are often altered by human development (Nichols et al., 1986; Emmett et al., 2000; Lotze et al., 2006).

The thermal transition that diadromous fish species experience in estuaries is important because temperature affects so many aspects of their biology (Magnuson, 2010) and has been called the abiotic "ecological master factor" (Brett, 1971). For example, temperatures that adult Pacific salmon (Oncorhynchus spp.) experience in coastal marine waters and during upriver migration can affect survival (Gilhousen, 1990;
Hinch et al., 2012), maturation (Roscoe et al., 2010), and reproductive success (Minke-Martin et al., 2018). Consequently, adult Pacific salmon and Atlantic salmon (Salmo salar) show many behavioral responses to temperature, including changes in vertical distribution at sea (Quinn et al., 1989; Tanaka et al., 2000; Walker et al., 2000), holding in river plumes outside estuaries (Cooke et al., 2008; Strange, 2013), changing vertical distribution in estuaries (Olson and Quinn, 1993), delay in upriver migration (Kristinsson et al., 2015), use of cool tributaries or deep pools (Berman and Quinn, 1991; Goniea et al., 2006; Strange, 2010; Moore et al., 2012), or spending the summer below the thermocline in lakes (Newell and Quinn, 2005; Mathes et al., 2010).

Many Pacific salmon populations experiencing high water temperatures are at low levels of abundance, and salmon experience en route or prespawning mortality in some years (Gilhousen, 1990; Richter and Kolmes, 2005; Hinch et al., 2012). Temperatures are predicted to continue to increase in the future, exacerbating the problem (Yates et al., 2008; Mantua et al., 2010). The changing thermal regimes may be especially 
stressful for populations migrating through estuaries and river corridors that have been modified through channelization, reducing suitable holding habitat, and where structures such as locks and dams have altered tidal regimes and hydrology (Hallock et al., 1970; Potter, 1988; Russell et al., 1998; Holbrook et al., 2009).

The combination of warming conditions and habitat alteration is exemplified by Lake Washington (Fig. 1), in Washington (Williamson et al., 2009), where adult Chinook salmon (O. tshawytscha) enter from July through September-the warmest period of the year (Fig. 2A). Temperatures in the lake and tributaries have been increasing, especially in summer (Quinn et al., 2002; Winder and Schindler, 2004; Fig. 2B). In contrast to large systems like the Columbia River, where salmonids use tributary junctions as thermal refuges (Keefer et al., 2018), and some small rivers apparently lacking thermal refuges (Hasler et al., 2012), the Lake Washington system's primary thermal refuge is stratification in the lake, but other small-scale thermal structures (i.e., river confluence and pools in rivers) also are available. The system also poses special challenges for salmon, including an abrupt change in salinity from Puget Sound to the migration corridor above the locks and low dissolved oxygen (DO) levels in parts of the corridor. Increasing

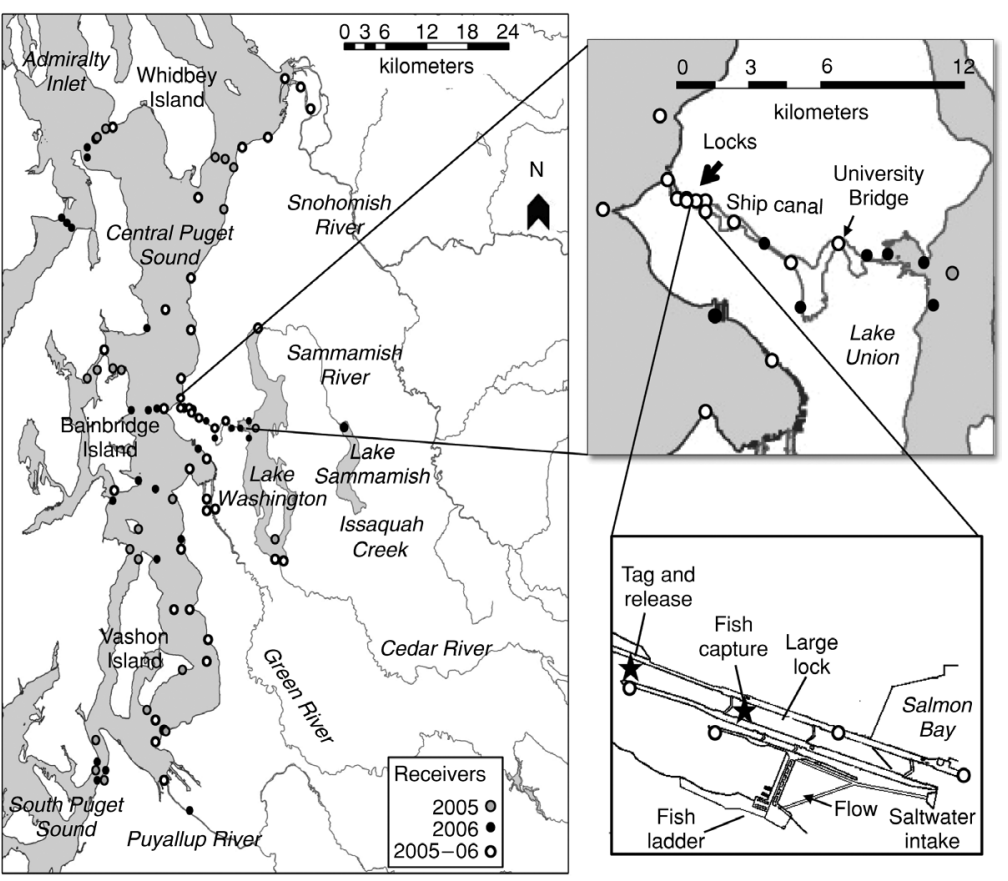

Figure 1

Map showing the acoustic monitoring network in coastal waters near Puget Sound, in western Washington, used to track the migration of tagged adult Chinook salmon (Oncorhynchus tshawytscha) in 2005 and 2006. The shade of circles indicates the year of deployment of acoustic receivers. The other maps show locations of receivers (circles) and of tagging and release events (stars) in the ship canal (top) and locks (bottom) in Lake Washington. temperatures may adversely affect migration rate and spawning success of Chinook and other salmon species in this system, and elsewhere (Connor et al., 2019), but the nature and extent of the effects may depend on the behavioral thermoregulation and other tactics used by salmon migrating through these altered waterways.

In this study, we used acoustic transmitters and archival temperature loggers to determine how adult Chinook salmon migrate through a complex sequence of structures and ambient water conditions from a small, marineinfluenced estuary through a set of locks and a shallow, warm navigation canal into a large, stratified lake and then into tributaries for spawning. We sought to determine whether segments of the migration route have conditions that delay migration and expose salmon to thermal stress from elevated temperatures that might affect survival and reproductive success. We did so by posing the following questions: 1) do Chinook salmon move back and forth between marine and fresh water prior to upriver migration? 2) do water temperatures experienced in fresh water affect transit time? 3) do the salmon minimize exposure to warm water by moving to deeper, cooler water where available? and 4) is use of cool water affected by ambient DO concentration and salinity? In this context, we use the term experience to indicate the thermal and other environmental conditions in the water the fish occupied, without making any implication regarding preference or avoidance.

\section{Materials and methods}

\section{Study area}

Puget Sound is a large $\left(3700 \mathrm{~km}^{2}\right)$ fjord system in western Washington bordered by British Columbia, Canada, to the north (Fig. 1). The Lake Washington watershed covers $1274 \mathrm{~km}^{2}$ and flows from tributaries of Lakes Sammamish and Washington through a navigation channel (henceforth, the ship canal) through the north end of Lake Union, to the Hiram M. Chittenden Locks (henceforth, the locks), and into Shilshole Bay. Salmon Bay, immediately upstream of the locks, has a saltwater wedge, and we refer to this bay as the upper estuary and to the area from the locks down to Shilshole Bay as the lower estuary. The lower estuary has summer mean temperatures of $12-13^{\circ} \mathrm{C}$ and salinity of 15-30. The saltwater wedge intrudes up to $6 \mathrm{~km}$ into the ship canal above the locks, but the highest salinities (1-20) and most mixing are within $1 \mathrm{~km}$ of the locks (Fig. 1, insets). The ship canal is $12.5 \mathrm{~km}$ long from Shilshole Bay to Lake Washington $(10.8 \mathrm{~km}$ from the 

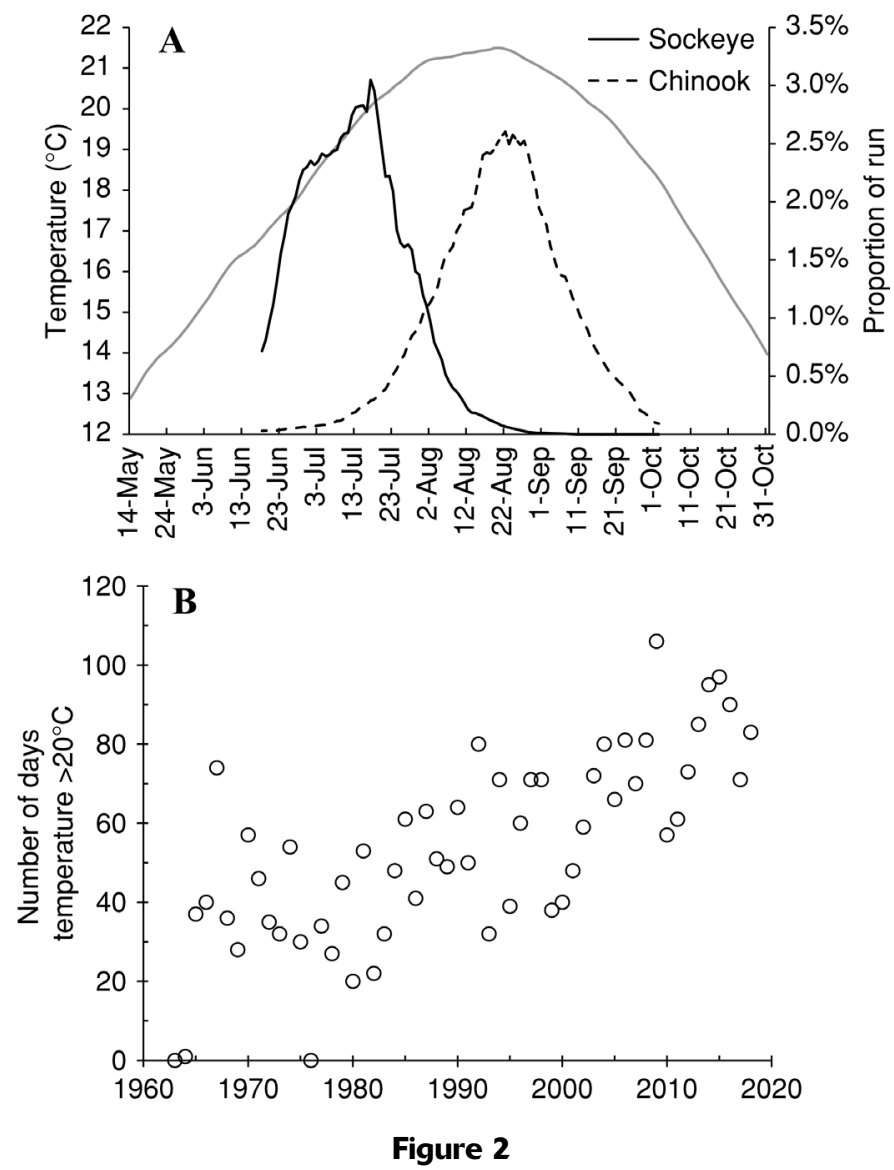

(A) Migration timing of sockeye (Oncorhynchus nerka) and Chinook (O. tshawytscha) salmon at the locks in the Lake Washington watershed in Washington (black lines) and mean lock temperature (gray line) during May-October in 2005 and 2006. The timing of migration (black lines) is presented as the proportion of the time of the run fish spent at various temperatures. (B) Number of days, by year, between the first and last days when the epilimnetic temperatures exceeded $20^{\circ} \mathrm{C}$ in Lake Washington. Data were provided by C. DeGasperi, King County Department of Natural Resources and Parks, Seattle, Washington.

locks to the lake) with a mean depth of $9 \mathrm{~m}$ and includes shallow Lake Union (mean depth: $10.5 \mathrm{~m}$; maximum: $16 \mathrm{~m}$ ). Lake Washington has a surface area of $87.6 \mathrm{~km}^{2}$, a mean depth of $32.9 \mathrm{~m}$ (maximum: $65.2 \mathrm{~m}$ ), and a summer epilimnion to about $10 \mathrm{~m}$. Lake Washington's 2 largest tributaries are the Cedar River and the Sammamish River, which drains Lake Sammamish (surface area: $21 \mathrm{~km}^{2}$; mean depth: $18 \mathrm{~m}$ ).

The locks include a tidally influenced fish ladder, small (8 $\mathrm{m}$ deep) and large (16 $\mathrm{m}$ deep) lock chambers, a spillway bay ( $5 \mathrm{~m}$ deep), and a drain above the large lock to return salt water to Puget Sound. The large lock is used by migrating salmon and is included in the area defined as the lower estuary. The locks physically separate the freshwater system, without any tidal elevation changes, from the marine system where tidal amplitudes reach $4 \mathrm{~m}$.
The exchange of fresh and salt water occurs predominantly in localized pulses during locking events, resulting in unusual circulation patterns within the estuarine portion of the ship canal. Salt water enters when the locks lift vessels from Puget Sound up and into the ship canal; therefore, temperatures in the large lock chamber can change up to $9^{\circ} \mathrm{C}$ in less than $1 \mathrm{~h}$. Salt water intrusion in spring and early summer is usually restricted to the lower $1.5 \mathrm{~km}$ of the ship canal, but by late summer it reaches Lake Union (4-6 $\mathrm{km}$ upstream), although at lower concentrations (salinity: 0-2) than near the locks (salinity up to 15). Vertical stratification in temperature and salinity occurs in Puget Sound, below the locks, within the large lock, in the saltwater wedge in Salmon Bay, in the ship channel (salinity only), and in Lake Union, and temperature stratification occurs in Lake Washington and Lake Sammamish. Low DO levels ( $<5 \mathrm{mg} / \mathrm{L})$ occur near the bottom from the upper estuary starting in August until the end of September.

\section{Fish capture and tagging}

In 2005 and 2006, the Washington Department of Fish and Wildlife (WDFW) and R2 Resource Consultants $^{1}$ (R2, Redmond, WA) captured 368 Chinook salmon by using a purse seine in the lower half of the large lock from early August through early September, tagged, and immediately released them below the locks in the lower estuary. This net was designed for sampling and safely releasing juvenile salmonids (Durkin and Park, 1967; Ledgerwood et al., 1991), and only fish in good condition were used for tagging, in an effort to minimize the effects of handling on fish survival and behavior. Catch and release, from commercial, scientific, and recreational fisheries, can affect survival, physiology, and behavior of salmon, but the effects are context dependent (Candy et al., 1996; Donaldson et al., 2011; Raby et al., 2015). Given the nature of our study system, there was no way to know how salmon would have behaved had we not caught and tagged them, nor did it allow us to compare survival rates among salmon with different types of tags. However, our goal was not to assess survival, it was to examine thermoregulatory behavior, for which our approach was standard and appropriate.

The Chinook salmon had both archival temperature data loggers, implanted by using tagging techniques similar to those in Newell and Quinn (2005), and passive integrated transponder (PIT) tags; approximately $25 \%$ also received acoustic tags (Table 1). These types of tags yield different but complementary kinds of information. The fish ladder

\footnotetext{
${ }^{1}$ Mention of trade names or commercial companies is for identification purposes only and does not imply endorsement from the National Marine Fisheries Service, NOAA.
} 


\section{Table 1}

Mean length of adult Chinook salmon (Oncorhynchus tshawytscha) captured and tagged in coastal waters near Puget Sound in Washington in 2005 and 2006, and associated tagging and recovery data for discrete weekly tagging events. Standard deviations of mean lengths are given in parentheses. PIT=passive integrated transponder.

\begin{tabular}{|c|c|c|c|c|c|c|}
\hline Tag and release date & $\begin{array}{l}\text { Mean fork } \\
\text { length (mm) }\end{array}$ & $\begin{array}{c}\text { No. of } \\
\text { archival/PIT } \\
\text { tags }\end{array}$ & $\begin{array}{c}\text { No. of } \\
\text { acoustic tags }\end{array}$ & $\begin{array}{l}\text { No. of PIT } \\
\text { detections }\end{array}$ & $\begin{array}{c}\text { No. of } \\
\text { archival } \\
\text { recoveries }\end{array}$ & $\begin{array}{l}\text { No. of archival } \\
\text { and acoustic } \\
\text { recoveries }\end{array}$ \\
\hline 11-Aug-05 & $780.7(84.7)$ & 19 & 15 & 5 & 4 & 3 \\
\hline 17-Aug-05 & $738.1(117.5)$ & 57 & 7 & 11 & 9 & 1 \\
\hline 24-Aug-05 & $735.1(82.0)$ & 72 & 10 & 17 & 27 & 3 \\
\hline 31-Aug-05 & $750.1(105.7)$ & 50 & 10 & 7 & 19 & 4 \\
\hline Mean or total for 2005 & $744.1(99.8)$ & 198 & 42 & 40 & 59 & 11 \\
\hline 9-Aug-06 & $795.7(63.9)$ & 50 & 19 & 12 & 13 & 7 \\
\hline 16-Aug-06 & $768.4(96.0)$ & 32 & 11 & 3 & 8 & 4 \\
\hline 23-Aug-06 & $820.3(72.3)$ & 29 & 9 & 2 & 11 & 2 \\
\hline 30-Aug-06 & $789.7(64.5)$ & 32 & 7 & 4 & 13 & 3 \\
\hline 6-Sep-06 & $796.7(64.8)$ & 21 & 5 & 0 & 6 & 1 \\
\hline 13-Sep-06 & $842.0(117.3)$ & 10 & 2 & 2 & 3 & 0 \\
\hline Mean or total for 2006 & $794.2(82.6)$ & 174 & 53 & 23 & 54 & 17 \\
\hline
\end{tabular}

had PIT tag detectors in a pool immediately upstream of the exit, indicating the proportion of fish using the ladder. Archival loggers attached externally, just behind the dorsal fin, recorded ambient temperatures experienced by the salmon. For data loggers, we used model iBCod (Alpha Mach, Ste-Julie, Quebec) type Z (high resolution $\pm 0.125^{\circ} \mathrm{C}$, precision $\pm 1^{\circ} \mathrm{C}$, temperature range of $-5-26^{\circ} \mathrm{C}$, weight of $12 \mathrm{~g}$ in air), a size appropriate for tagging fish $50-100 \mathrm{~cm}$ in fork length, and attached them to the salmon by using nickel pins and vinyl disks. The temperature loggers recorded data hourly for $95 \mathrm{~d}$ but had to be recovered to acquire the data. Moreover, the precise location of the fish had to be inferred from the thermal regime or detection of a transmitter in the fish (if it had one) when it passed a receiver.

Locations of 95 Chinook salmon were determined by using acoustic transmitters weighing $\leq 12$ g. Vemco (Bedford, Canada) V13-1L (22) and V13P-1L pressure sensors (63) and V9-6L (11) acoustic tags, with 20-60 s and 30-90 s minimum and maximum pulse rates (or intervals between each signal transmission), were inserted into stomachs. The detection range of the tags in marine and deep areas in fresh water was about 100-400 $\mathrm{m}$ for the V9 and 200-600 $\mathrm{m}$ for the V13 tags. Detection ranges for all tags declined to about $10-100 \mathrm{~m}$ in shallow areas and were affected by proximity to the shoreline, fish depth, and other local features.

\section{Data retrieval from tags and environmental monitors}

Vemco VR2 acoustic receivers (16 in 2005 and 21 in 2006) were installed along the migration corridor (Fig. 1; see also Goetz, 2016) before the Chinook salmon were tagged and before they were retrieved after the spawning season. All detections were checked, and erroneous records, inconsistencies, and data anomalies were removed. Data from other researchers were obtained either through direct contact or from online databases (Hydraphone Data Repository, available from website; Ocean Tracking Network, available from website). Four sets of antennae and PIT tag readers were installed in the fish ladder; sequential detections indicated the direction of movement.

To characterize the conditions available to salmon, we obtained data on salinity, temperature, and DO concentration from fixed stations and from water-quality data collected by various agencies (Table 2), including data in the large lock during $1 \mathrm{~d}$ each year of the study by measuring temperature and salinity changes over a series of lock-filling events. We monitored temperature hourly in the large lock during the course of the study by using a thermometer at a depth of $10 \mathrm{~m}$ (in 2005) and near surface (in 2006).

\section{Data analysis}

Telemetry data indicating time and depth at fixed receivers were combined with hourly data from archival temperature loggers to reveal the thermal experience of individual fish along their route. This was done by constructing, for each fish, a chronology by merging the logger data (with temperature, date, and time) with the receiver data (with date, time, and depth, at fixed locations). Salmon were excluded from analysis if they apparently died, they were not detected upriver of the locks, or the date and location of the recovery of their archival tag could not be verified. Analyses were designed to describe the behavior and environmental experience of fish by recovery location and by segment of the migration route. The segments were as follows: 1) marine waters of Puget Sound to the locks, 2) upper estuary above the locks in Salmon Bay, 3) ship canal and Lake Union, 4) Lake Washington, including the deltas of the Sammamish River and the Cedar River, 5) the 


\section{Table 2}

Information about the water-quality stations along the salmon migration corridor from Puget Sound to spawning streams in Washington, including the period of record considered for this study of adult Chinook salmon (Oncorhynchus tshawytscha), frequency of measurements, depth, and parameters used. Data sources are the U.S. Army Corps of Engineers, Muckleshoot Tribe, and King County Department of Natural Resources. Parameters include temperature (Temp), dissolved oxygen concentration (DO), salinity (Sal), and rate of flow (Flow).

\begin{tabular}{lrlllll}
\hline Ship canal location & Year & Frequency & Depth $(\mathrm{m})$ & Parameters & Latitude & Longitude \\
\hline Marine, West Point & $2000-09$ & Monthly & $1-25+$ & Temp, DO, Sal & 47.663 & -122.448 \\
Shilshole Bay & $2005-06$ & Hourly & $0.5,1,4$ & Temp, Sal & 47.666 & -122.400 \\
Large lock & $2005-06$ & Hourly & 1,10 & Temp & 47.665 & -122.396 \\
Salmon Bay 1 & $2005-06$ & Hourly & $5.3,8.3,11,13$ & Temp, Sal & 47.665 & -122.395 \\
Salmon Bay 2 & $2005-06$ & Hourly & $2,5,7,9-13$ & Temp & 47.665 & -122.392 \\
Salmon Bay & 2006 & Weekly & $1-15$ & Temp, DO, Sal & 47.665 & -122.394 \\
Ship Canal West & 2005 & Weekly & $1-9$ & Temp, DO, Sal & 47.656 & -122.367 \\
Lake Union North & $2005-06$ & Weekly & $1-12$ & Temp, DO, Sal & 47.643 & -122.336 \\
Ship Canal East & $2005-06$ & Weekly & $1-8$ & Temp, DO & 47.648 & -122.312 \\
Lake Washington & $2005-06$ & Hourly & $2,6,8,10,20$ & Temp & 47.643 & -122.271 \\
Cedar River & $2005-06$ & Hourly & 1 & Temp, Flow & 47.482 & -122.203 \\
Sammamish River 1 & $2005-06$ & Hourly & 1 & Temp, Flow & 47.703 & -122.143 \\
Sammamish River 2 & $2005-06$ & Hourly & 1 & Temp, Flow & 47.662 & -122.124 \\
Cottage Creek & $2005-06$ & Hourly & 1 & Temp, Flow & 47.717 & -122.088 \\
Issaquah Creek & $2005-06$ & Hourly & 1 & Temp & 47.552 & -122.048
\end{tabular}

Sammamish River, 6) Lake Sammamish, and 7) spawning tributaries, including the Cedar and Sammamish Rivers and Issaquah, Cottage, and Kelsey Creeks.

Telemetry data indicate the residence time (defined by the first and last detections) in each migration segment. For fish with only archival temperature data, we inferred the transitions between segments by comparing that fish's temperature record with those of fish carrying both archival and acoustic tags (Table 1, Fig. 3). Residence time by migration segment was evaluated through analysis of variance (ANOVA) with year and tagging week as factors, by using the duration of residence and also the proportion of the total time spent in a migration segment. For fish with acoustic tags, the depth recorded on the receiver was used to estimate the ambient temperature based on vertical thermal profiles at that location (Table 2). A 2-way ANOVA was used to test for significant differences between years and among weekly tagging groups for each metric.

Mean daily temperatures were calculated from archival tag records of temperatures experienced by individual fish. The accumulated degree days (DD, mean daily temperature exposure above $0^{\circ} \mathrm{C}$ ) for each fish were calculated by summing the mean daily temperatures it experienced during the entire migration or in specific migratory segments. To assess possible cumulative stress, mean daily temperatures that exceeded thresholds of $18.0^{\circ} \mathrm{C}$ and $20.0^{\circ} \mathrm{C}$ were also summed for each migrant. These 2 thresholds are associated with stress response in Pacific salmon (McCullough et al., 2009; Eliason et al., 2011) and with potential changes in behavior for thermoregulation (e.g., Berman and Quinn, 1991; Goniea et al., 2006).

\section{Results}

\section{Movements and residence time}

All but 1 of the 95 acoustic-tagged Chinook salmon were detected at least once in the Lake Washington basin, and 63 PIT-tagged fish were detected in the fish ladder (40 in 2005 and 23 in 2006). Archival tags were recovered from 113 salmon, primarily in spawning streams and in the hatchery that raises Chinook salmon on Issaquah Creek. Data were also collected from 28 fish with both archival and acoustic tags (Table 1). The transmitters provided over 450,000 detections for up to $61 \mathrm{~d}$. We reduced the number for analysis to 62 fish by removing fish that had transmitter failure or malfunction that limited the number of detections, died or had a regurgitated tag, left the watershed, or remained in the lower estuary. After entering the lower estuary following tagging, 51\% of acoustictagged fish moved continuously upstream, 21\% returned once to Puget Sound, $16 \%$ returned twice, and $13 \%$ returned 3 or more times. To reach the upper estuary, $17 \%$ of the fish used the fish ladder and $83 \%$ used the large lock, as indicated by PIT-tag detections. After reaching the upper estuary, $62 \%$ of the fish continued upstream, $21 \%$ returned once to the lower estuary, $9 \%$ returned twice, and $8 \%$ returned 3 or more times.

Individual Chinook salmon displayed diverse patterns of thermal experience, resulting from time spent in different areas along the migration route: cool in the lower estuary, warm in the upper estuary and ship canal, and cool in Lake Washington's deep waters. In addition to variation in thermal experience arising from horizontal movement patterns, some fish remained below the thermo-halocline, 

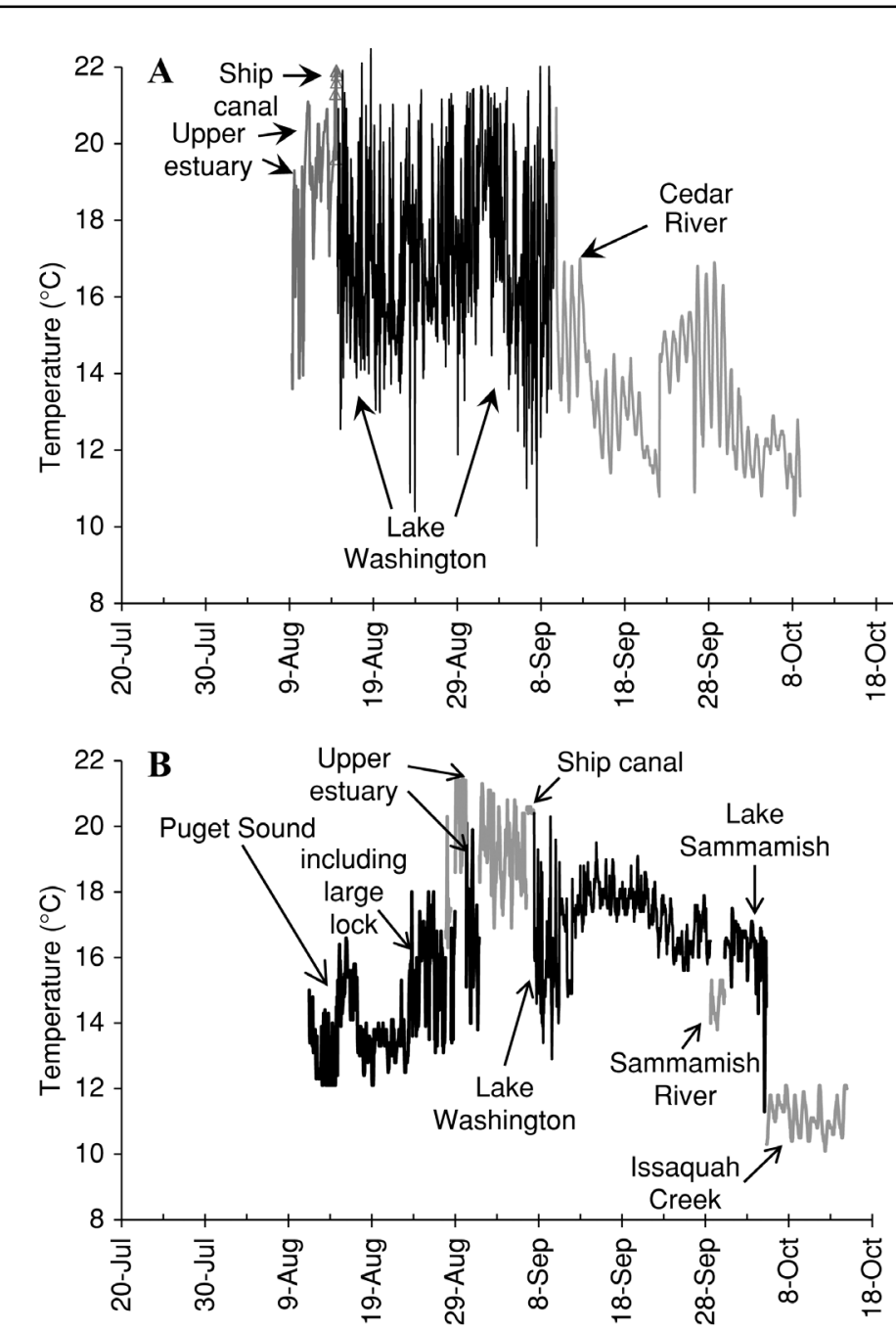

Figure 3

Typical hourly temperatures by location for Chinook salmon (Oncorhynchus tshawytscha) migrating from the upper estuary in the Lake Washington watershed, in western Washington, to their final capture location in (A) Cedar River and (B) Issaquah Creek during July-October in 2005 and 2006. ship canal to Lake Washington. Those migrating into the Lake Sammamish system spent, on average, $7.9 \mathrm{~d}$ in Lake Washington, $7.5 \mathrm{~d}$ in the Sammamish River, and $4.8 \mathrm{~d}$ in Lake Sammamish. Individuals returning to the Cedar River spent on average $20.2 \mathrm{~d}$ in Lake Washington before ascending the river-the same total period as those moving through to Lake Sammamish.

The proportion of total residence time in the estuary (lower and upper) was similar between years and tagging groups (mean: $47.1 \%$ [standard deviation (SD) 17.9], $P=0.36$; Table 3). However, there was an inverse relationship between time spent in the estuary and in Lake Washington (coefficient of correlation $[r]=-0.350, \mathrm{df}=91, P<0.001$ ) that tended to conserve the overall transit time. This correlation was significant and stronger in $2006(r=-0.546)$ than in $2005(r=-0.118)$.

\section{Environmental conditions available to Chinook salmon}

The temperatures along the migration route were coolest in Puget Sound (range: $10-18^{\circ} \mathrm{C}$ ), warmer in Salmon Bay $\left(15.4-22.6^{\circ} \mathrm{C}\right)$ and the ship canal $\left(17.3-22.5^{\circ} \mathrm{C}\right)$, and variable with depth in Lake Washington $\left(8.5-22.5^{\circ} \mathrm{C}\right.$; Table 4$)$. The estuary had a zone of dynamic short-term mixing of warm fresh water $\left(20-23^{\circ} \mathrm{C}\right)$ and colder salt water $\left(12-15^{\circ} \mathrm{C}\right)$ environments. The large lock and a small area of the upper estuary had a halocline at about $10 \mathrm{~m}$; the upper estuary's halocline had warmer surface water in August than that of the large lock $\left(19.5^{\circ} \mathrm{C}\right.$ versus $\left.15.5^{\circ} \mathrm{C}\right)$. The $\mathrm{DO}$ levels at lower depths $(13-10 \mathrm{~m})$ in the upper estuary ranged from 5.7 to $7.1 \mathrm{mg} / \mathrm{L}$, whereas in Lake Washington DO concentration at similar depths ranged from 6.4 to $7.4 \mathrm{mg} / \mathrm{L}$.

The upper estuary was slightly warmer than Lake Washington $\left(20.8^{\circ} \mathrm{C}\right.$ versus $\left.20.2^{\circ} \mathrm{C}\right)$ at depths from 2 to $10 \mathrm{~m}$, and more so at $12 \mathrm{~m}$ (just above the typical thermocline depth: $19.6^{\circ} \mathrm{C}$ versus $17.9^{\circ} \mathrm{C}$; Table 4 ). In 2005 , it was $1.3^{\circ} \mathrm{C}$ warmer than in 2006 at all depths above $12 \mathrm{~m}$ in the occupied cooler temperatures in the late afternoon and evening, and rose in the water column to shallower depths during the rest of the 24 -h period.

The Chinook salmon reached the spawning grounds slightly faster in 2005 than in 2006 (mean: 34.1 and $36.0 \mathrm{~d}$, respectively, $F=6.5, P<0.01$; Table 3 ), and fish tagged earlier in August were slower in 2005 and 2006 (mean: 41.5 and $37.1 \mathrm{~d}$, respectively) than those tagged later in both years (mean: 31.0 and $33.8 \mathrm{~d}$, respectively). The salmon took longer to move through the lower estuary (from Puget Sound to Salmon Bay) in 2005 than in 2006 but moved through the upper estuary faster in 2005 than in 2006; therefore, the overall time was similar between years. Once they exited the upper estuary, Chinook salmon moved quickly (mean: $0.6 \mathrm{~d}$ ) through the $10.8 \mathrm{~km}$ from the upper estuary and $0.4^{\circ} \mathrm{C}$ warmer in Lake Washington at depths above $10 \mathrm{~m}$. Temperatures in the upper estuary were similar at depth between August and September in 2005 , whereas in 2006 temperatures were more than $2.0^{\circ} \mathrm{C}$ cooler in August than in September at each depth. Lake Washington temperatures in August at depths $<10 \mathrm{~m}$ were slightly warmer in 2005 than in 2006, and temperatures were similar each year in September; in both years August was $1-2^{\circ} \mathrm{C}$ warmer than September.

\section{Depths and temperatures experienced by Chinook salmon}

The depths occupied by Chinook salmon varied by reach and were influenced by bottom depth and the presence of thermal stratification (Fig. 4; see also Goetz, 2016). 


\section{Table 3}

Residence times of adult Chinook salmon (Oncorhynchus tshawytscha) tagged in Lake Washington in western Washington during 2005 and 2006, with mean number of days and standard deviations (SDs) given in the upper table and mean proportions of time and SDs provided in the lower table, by migration segment and year. Residence times were measured by acoustic (number of tags $[n]=26$ ) and archival $(n=67)$ tags or by archival tags only. For each migration segment, the number of tags used to generate the estimate is shown in parentheses.

\begin{tabular}{|c|c|c|c|}
\hline \multirow[b]{2}{*}{ Migration segment (no. of tags) } & \multicolumn{3}{|c|}{ Mean number of days (SD) } \\
\hline & 2005 & 2006 & Grand \\
\hline Estuary (lower and upper: 93) & $15.8(7.3)$ & $17.2(7.7)$ & $16.5(7.5)$ \\
\hline Ship canal (92) & $0.6(0.3)$ & $0.4(0.3)$ & $0.5(0.3)$ \\
\hline Lake Washington (93) & $6.8(6.5)$ & $8.9(7.9)$ & $7.9(7.3)$ \\
\hline Sammamish River (66) & $8.8(6.2)$ & $6.3(6.0)$ & $7.5(6.2)$ \\
\hline Lake Sammamish (62) & $4.6(3.9)$ & $4.8(4.1)$ & $4.7(3.9)$ \\
\hline \multirow[t]{2}{*}{ Total } & $34.1(9.7)$ & $36.0(8.9)$ & $35.1(9.3)$ \\
\hline & \multicolumn{3}{|c|}{ Mean proportion of time (SD) } \\
\hline Migration segment & 2005 & 2006 & Grand \\
\hline Estuary (lower and upper) & $47 \%(19)$ & $47 \%(17)$ & $47 \%(18)$ \\
\hline Ship canal & $2 \%(1)$ & $1 \%(1)$ & $2 \%(1)$ \\
\hline Lake Washington & $15 \%(12)$ & $20 \%(21)$ & $18 \%(17)$ \\
\hline Sammamish River & $24 \%(16)$ & $17 \%(13)$ & $20 \%(15)$ \\
\hline Lake Sammamish & $13 \%(13)$ & $13 \%(10)$ & $13 \%(11)$ \\
\hline
\end{tabular}

\section{Table 4}

Temperatures experienced (ranges and means) by Chinook salmon (Oncorhynchus tshawytscha) during upriver migration in relation to tagging week in 2005 and 2006 in coastal waters of Washington near Puget Sound. Segments of migration include the lower and upper estuary of the Lake Washington watershed, ship canal, Lake Washington, Lake Sammamish, Sammamish River, and entryways of tributaries. Dates of tagging weeks are provided in Table 1.

\begin{tabular}{|c|c|c|c|c|c|c|c|c|c|c|c|c|c|}
\hline \multirow[b]{3}{*}{ Group } & \multicolumn{13}{|c|}{ Migration segment } \\
\hline & \multicolumn{2}{|c|}{ Lower estuary } & \multicolumn{2}{|c|}{ Upper estuary } & \multicolumn{2}{|c|}{ Ship canal } & \multicolumn{2}{|c|}{ L. Washington } & \multicolumn{2}{|c|}{ L. Sammamish } & \multicolumn{2}{|c|}{ Sammamish R. } & \multirow{2}{*}{$\frac{\text { Trib. entry }}{\text { Mean }}$} \\
\hline & Range & Mean & Range & Mean & Range & Mean & Range & Mean & Range & Mean & Range & Mean & \\
\hline Week 1 & $11.9-17.9$ & 14.0 & $16.3-21.9$ & 19.1 & $18.9-21.4$ & 20.4 & $9.6-21.4$ & 16.4 & $13.3-20.4$ & 17.4 & $13.0-19.5$ & 16.6 & 11.0 \\
\hline Week 2 & $12.1-17.8$ & 14.6 & $16.0-22.3$ & 19.1 & $17.9-22.0$ & 20.2 & $9.6-21.5$ & 17.1 & $13.0-20.4$ & 17.2 & $12.5-18.9$ & 15.2 & 12.5 \\
\hline Week 3 & $12.4-17.9$ & 14.7 & $16.0-22.6$ & 19.1 & $18.3-22.3$ & 20.4 & $9.3-21.5$ & 16.9 & $12.8-20.5$ & 16.9 & $12.5-19.3$ & 15.3 & 12.4 \\
\hline Week 4 & $12.5-18.3$ & 14.9 & $15.9-21.3$ & 18.5 & $18.0-20.6$ & 19.7 & $8.5-20.5$ & 16.8 & $11.9-19.4$ & 16.5 & $10.0-17.1$ & 14.5 & 12.2 \\
\hline Week 1 & $10.1-18.3$ & 13.8 & $15.4-22.5$ & 19.5 & $17.3-22.5$ & 20.9 & $9.5-22.5$ & 18.1 & $12.5-21.5$ & 17.1 & $13.1-21.0$ & 16.5 & 12.8 \\
\hline Week 2 & $11.9-17.4$ & 13.3 & $15.6-21.8$ & 18.9 & $18.1-22.1$ & 20.4 & $9.1-21.6$ & 17.5 & $13.0-20.3$ & 17.1 & $13.5-21.4$ & 16.7 & 12.7 \\
\hline Week 3 & $11.9-17.8$ & 14.4 & $15.9-20.9$ & 18.4 & $18.1-21.0$ & 19.8 & $10.6-21.1$ & 17.2 & $13.0-20.0$ & 17.2 & $13.1-19.3$ & 15.4 & 12.0 \\
\hline Week 4 & $13.3-18.0$ & 15.2 & $16.3-21.1$ & 18.7 & $17.4-21.1$ & 20.2 & $9.1-21.4$ & 17.4 & $13.0-20.5$ & 17.2 & $11.6-18.0$ & 15.3 & 12.3 \\
\hline
\end{tabular}

Chinook salmon in Puget Sound occupied depths from near the surface to $>150 \mathrm{~m}$ (mean: $15 \mathrm{~m}$ in 2005, $20 \mathrm{~m}$ in 2006). In the cooler, mixed lower estuary, most detections were at depths $<5 \mathrm{~m}$. In the large lock and upper estuary, they remained near the bottom at depths of 10-14 m. Most detections were at depths $<5 \mathrm{~m}$ in the ship canal, between 5-15 $\mathrm{m}$ in Lake Washington, and $<3 \mathrm{~m}$ near tributary deltas.

The archival data loggers provided 60,406 temperature records from Chinook salmon prior to entering spawning tributaries (mean: 875 records/fish; range: 477-1477 records/fish). Of these hourly records, $15.0 \%$ 

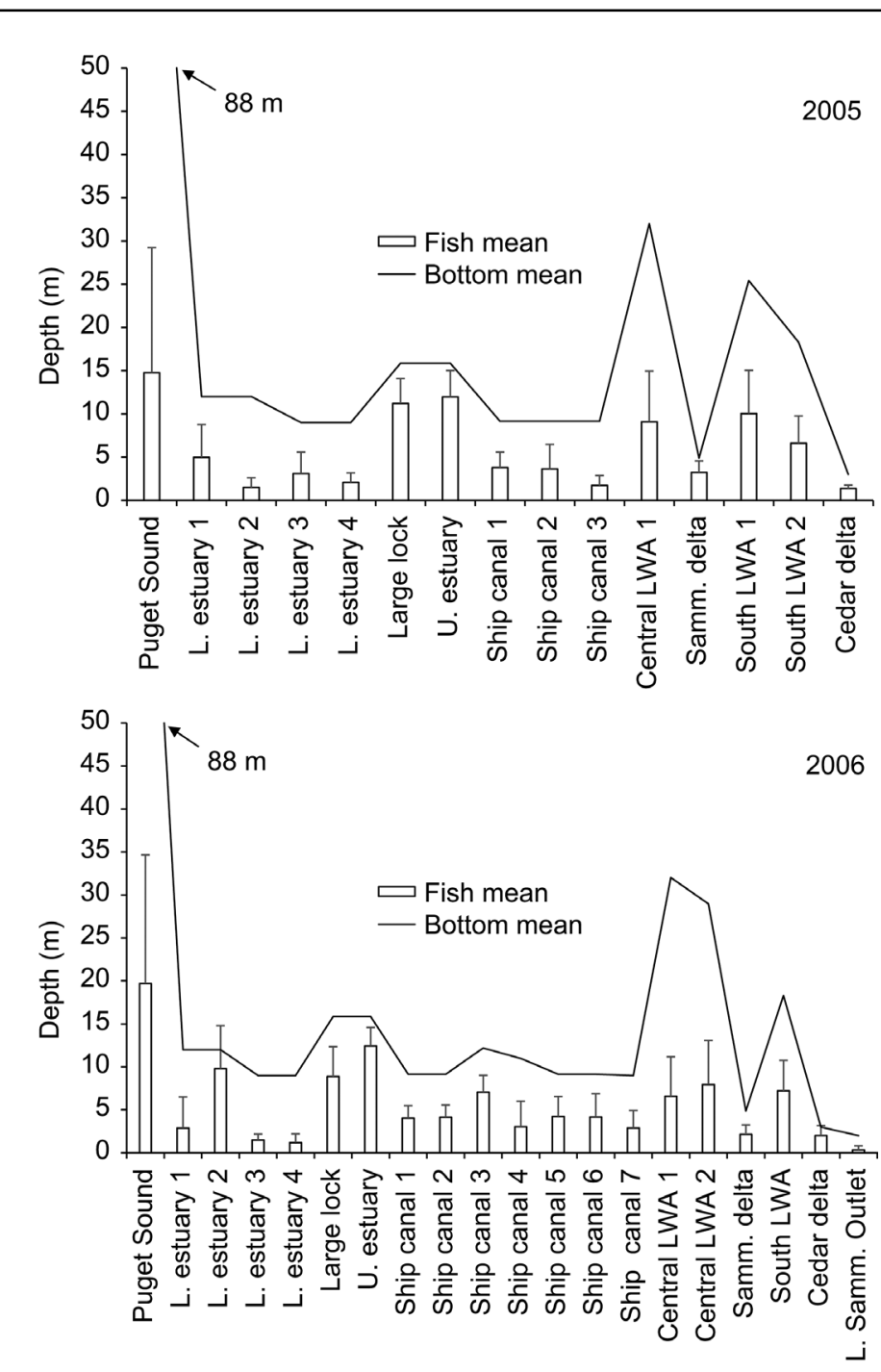

Figure 4

Mean depth of tagged Chinook salmon (Oncorhynchus tshawytscha) (bars) and mean bottom depth (solid line) near acoustic receivers along the migration route of Chinook salmon in 2005 and 2006. Locations in Washington where depth data were recorded include Puget Sound, the lower and upper estuary, the large lock, and the ship canal of the Lake Washington watershed, central and south Lake Washington (LWA), Sammamish River delta, Cedar River delta, and Lake Sammamish outlet. Error bars indicate standard deviations.

where the water was more uniformly warm. The highest temperatures and greatest change in temperatures fish experienced were from entry into the lower estuary (mean: $15.1^{\circ} \mathrm{C}$ ) to the fish ladder's exit (mean: $21.6^{\circ} \mathrm{C}$ ) for an average $2-\mathrm{h}$ change of $6.5^{\circ} \mathrm{C}$.

Cool, saline water near the bottom was more available during the day than at night because this water intruded during locking events, which took place primarily during the day. The typical behavior of Chinook salmon included holding for several days below the thermo-halocline in the lower estuary in the large lock (mean depth: $10 \mathrm{~m}$; salinity: 12-27) and upper estuary (mean depth: $13 \mathrm{~m}$; salinity: 1-18). Temperatures at the depths most often used varied markedly between the large lock $\left(14-17^{\circ} \mathrm{C}\right)$ and the upper estuary above the locks $\left(19-21^{\circ} \mathrm{C}\right)$. In the upper estuary, fish experienced warmer temperatures in the morning (mean: $19.9^{\circ} \mathrm{C}$ ) as their depth shallowed after dawn $(\sim 11 \mathrm{~m})$, through late morning, and then the temperatures decreased $\left(18.6^{\circ} \mathrm{C}\right)$ with the increased depth $(\sim 13 \mathrm{~m})$ into the evening. Therefore, despite the afternoon rise in temperatures at the surface, the temperatures occupied by the fish decreased. Cool, saline water at depth was increasingly available during the day because this water entered during locking events that occurred primarily during the day. Within Lake Washington, Chinook salmon occupied depths from near the surface to $>20 \mathrm{~m}$, above and below the thermocline (Figs. 3 and 4). Most $(73 \%)$ recorded temperatures were $15-20^{\circ} \mathrm{C}$, corresponding to depths near and above the thermocline (10-15 m; Fig. 5). In 2006, the salmon spent more time within $10 \mathrm{~m}$ of the surface than in 2005 , the warmer year (21\% versus $4 \%$ ).

The highest temperatures experienced by individual Chinook salmon were $22.6^{\circ} \mathrm{C}$ in 2005 and $22.5^{\circ} \mathrm{C}$ in 2006 . The average maxima among fish were the same $\left(21.4^{\circ} \mathrm{C}\right)$ in both years, with the warmest temperatures in the upper estuary $\left(22.6^{\circ} \mathrm{C}\right)$, Lake Washington $\left(22.6^{\circ} \mathrm{C}\right)$, the ship canal $\left(22.5^{\circ} \mathrm{C}\right)$, and Lake Sammamish $\left(21.5^{\circ} \mathrm{C}\right)$ (Fig. 6). All Chinook salmon experienced one or more $12-24$-h periods of temperatures $>18^{\circ} \mathrm{C}$, and $85 \%$ of salmon had one or more such periods $>20^{\circ} \mathrm{C}$. Overall, $40.1 \%$ of the records were $>18^{\circ} \mathrm{C}$,

were assigned to the lower estuary, $31.3 \%$ to the upper estuary, $1.4 \%$ to the ship canal, $21.0 \%$ to Lake Washington, $19.7 \%$ to the Sammamish River, and $11.6 \%$ to Lake Sammamish. Most individuals experienced a wide range of water temperatures with typical minima of $9-12^{\circ} \mathrm{C}$ and maxima of $20-22^{\circ} \mathrm{C}$ (examples in Figure 3 ). The fish experienced diel temperature fluctuations (warm in the afternoon and cool in early morning) in all areas, but daily ranges were greater (up to $4-6^{\circ} \mathrm{C}$ ) in Lakes Washington and Sammamish, moderate in the estuary and river $\left(2-3^{\circ} \mathrm{C}\right)$, and smallest in the ship canal $\left(1-2^{\circ} \mathrm{C}\right)$ and $2.1 \%$ were $>20^{\circ} \mathrm{C}$. Chinook salmon were not exposed to water $>18^{\circ} \mathrm{C}$ in Puget Sound but had extended exposure in the upper estuary (98\% of daily mean temperatures $>18^{\circ} \mathrm{C}$ in August) and in Lake Washington (45\% of daily means $>18^{\circ} \mathrm{C}$ in September).

Chinook salmon that arrived and were tagged earlier in the summer tended to spend longer in transit prior to entering a tributary for spawning than did those arriving later. Specifically, fish tagged in the first week spent an average of $50.7 \mathrm{~d}$ in 2005 and $42.7 \mathrm{~d}$ in 2006 , decreasing to $31.8 \mathrm{~d}$ in 2005 and $26.2 \mathrm{~d}$ in 2006 for the last group (Table 1). 


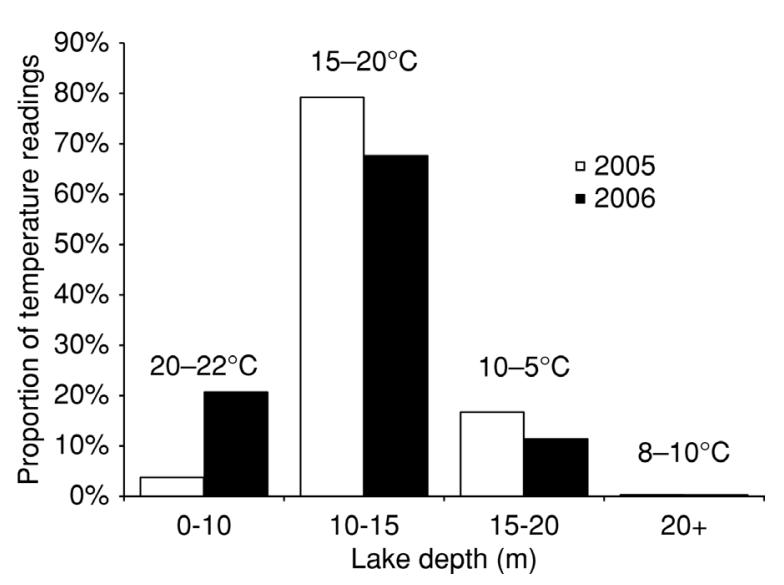

Figure 5

Proportions of temperature records, from tags implanted in Chinook salmon (Oncorhynchus tshawytscha), in Lake Washington in western Washington during 2005 and 2006 for each of the depth strata where those temperatures were experienced.

Therefore, there was more variation in arrival dates into the system than variation in ascent into spawning streams. The total thermal exposure (DD) from tagging to spawning stream ascent was higher in the early arriving fish (means for the first week: 844.4 in 2005 and 723.8 in 2006) than those arriving in the last week (means: 521.1 in 2005 and 449.3 in 2006) - a consequence of the warmer water experienced by and longer exposure of the earlier fish.

\section{Discussion}

The Chinook salmon entering the Lake Washington system faced environmental challenges that are both unique and generic. Few rivers that salmon ascend have locks between fresh and salt waters, and such structures produce unusual combinations of temperature, salinity, and DO level with abrupt changes over short temporal and spatial scales, both vertically and horizontally. However, although the physical structure and these features of the environment are unique, the system is experiencing the increases in temperature (Fig. 2) that also characterize many migratory corridors for salmonids and other fish species (Quinn, 2018). In this context, the increasing temperatures in Lake Washington are simply part of a much broader pattern of climate-driven change, although each river and lake has its own characteristics. These temperatures pose challenges for salmon; therefore, further information on how they confront thermal barriers will be important to determine their likelihood of survival (Hasler et al., 2012; Fenkes et al., 2016; Connor et al., 2019).

We posed a series of questions to help characterize the ways in which Chinook salmon address these challenges, either by making use of refuges and other forms of avoidance when confronted with adverse conditions or by tolerating the conditions. In addition, given the later migration in the season and generally warmer water experienced by Chinook salmon compared with that experienced by sympatric sockeye salmon (O. nerka) (Newell and Quinn, 2005), we predicted that the former would show greater tolerance of higher temperatures. In the modified Lake Washington estuary, Chinook salmon occupied thermal refuges in stratified marine and freshwater areas. Most Chinook salmon left the estuary after tagging and spent a few days in Puget Sound, often below the thermo-halocline. Upon return to the upper estuary, they either held in the saltwater wedge for a week or more or went back to Puget Sound again. These movements may have been responses to the abrupt change in salinity. If the fish were not fully tolerant of fresh water, the scarcity of intermediate salinities may have stimulated them to return to Puget Sound and to enter the ship canal again a few days later. To reach the upper estuary, most Chinook salmon migrated through the locks and were often below the thermo-halocline in the lock, where temperatures were intermediate between those in Puget Sound and the upper estuary. A smaller fraction of the Chinook salmon ascended the fish ladder. Temperatures in the ladder were much warmer than in the locks because it contained the surface water from the ship canal. Although the tendency to use the locks rather than the ladder was consistent with avoidance of warm water, it is certainly not proof of it, as the structures differ in many other physical aspects besides temperature.

The warmest and likely most stressful conditions that all Chinook salmon had to experience were in the upper estuary, which received little marine input and was dominated by the warm surface waters from Lake Washington and Lake Union. Fish there occupied the deepest waters below the thermo-halocline for extended periods prior to migration to Lake Washington, apparently balancing the benefits of low temperature against the drawbacks of low DO concentration. Chinook salmon tagged during the warmest periods in early August remained longer in the estuary (lower and upper) before migrating rapidly upstream through the ship canal than did those arriving in September, when the water was slightly cooler. Once in Lake Washington, most fish resided for some period at depths near the thermocline with vertical migrations to use cooler water, and they eventually moved toward shallower river deltas where they experienced high temperatures before entering rivers with cooler water.

Despite avoiding the warmest surface waters, all Chinook salmon experienced temperatures $>18^{\circ} \mathrm{C}$ and $85 \%$ of the Chinook salmon experienced temperatures $>20^{\circ} \mathrm{C}$, a threshold associated with adult migration delay, stress, and potential mortality (Goniea et al., 2006; Keefer et al., 2009). Chinook salmon in the upper estuary and Lake Washington occupied vertical positions that minimized their exposure to the warmest temperatures, as do Pacific salmon in other man-made and natural impoundments (Keefer et al., 2009; Strange, 2012; Keefer et al., 2015). Diel patterns in the upper estuary followed those seen in some other salmonids: deeper during the day than at night (Newell and Quinn, 2005; Mathes et al., 2010; Roscoe et al., 


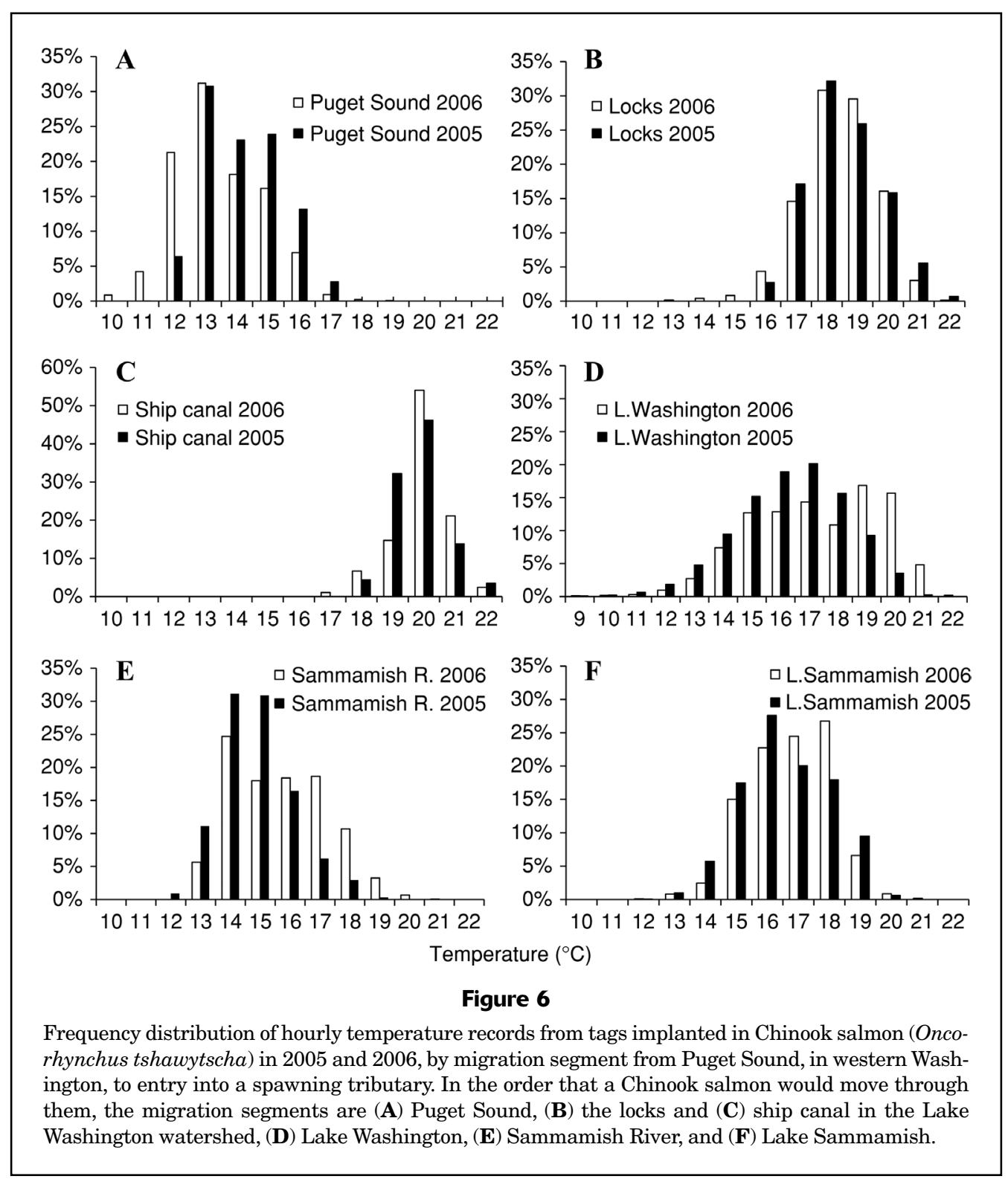

2010), although Chinook salmon in Puget Sound did not display diel vertical migrations (Smith et al., 2015). Even with behavioral adaptation, fish residing in the upper estuary were continuously exposed to potentially stressful temperatures $\left(18-21^{\circ} \mathrm{C}\right)$ while experiencing pulses of brackish water (1-18) and variable periods of low DO concentration $(<6 \mathrm{mg} / \mathrm{L})$. The available alternatives to this refuge were to revisit marine waters or swim up $10.8 \mathrm{~km}$ through even warmer waters $\left(21-22^{\circ} \mathrm{C}\right)$ to Lake Washington. Lake Union provided access to cooler water $\left(14-15^{\circ} \mathrm{C}\right.$ at a depth of $11 \mathrm{~m}$ ) between the upper estuary and Lake Washington, but the salmon did not occupy this habitat. In that lake, DO levels below the thermocline were $<5 \mathrm{mg} / \mathrm{L}$ in August and early September (USACE ${ }^{2}$ ), a level causing

\footnotetext{
${ }^{2}$ USACE (U.S. Army Corp of Engineers). 2005-2006. Unpubl. data. P.O. Box 3755, Seattle, WA 98124-3755.
}

avoidance or delay in migrating Pacific salmon (Fujioka, 1970; Hallock et al., 1970; Alabaster, 1989). In Lake Washington, Chinook salmon had access to cooler water below the thermocline without restriction by low DO concentration, yet they did not occupy such depths, in contrast to sockeye salmon (Newell and Quinn, 2005).

Comparisons to salmonids in other systems reveal a variety of responses to adverse conditions along the migratory corridor. Most Chinook salmon tagged in the Klamath River's estuarine lagoon returned to the ocean and remained for about $10 \mathrm{~d}$ near the river plume before moving upriver (Strange, 2013), as did Chinook salmon in our study although for a shorter period. Similarly, some sockeye salmon populations hold in the Fraser River plume prior to upriver migration (Cooke et al., 2008). The migratory behavior of Pacific salmon returning to estuaries and rivers includes several species (e.g., Chinook salmon, 
sockeye salmon, and steelhead, O. mykiss) that exhibit diel vertical movement patterns in stratified and unstratified waters (Drenner et al., 2012). Limited available data indicate that salmon in estuaries are often associated with thermo-haloclines (Brawn, 1982; Westerberg, 1982; Døving et al., 1985; Potter, 1988; Olson and Quinn, 1993; Strange, 2013), although vertical distribution is not always related to oceanographic conditions (Quinn et al., 1989; Ruggerone et al., 1990; Walker et al., 2000; Ishida et al., 2001). In the Columbia River estuary, individual Chinook salmon made complex vertical movements relative to varying thermal and salinity gradients (Olson and Quinn, 1993). Vertical placement near clines presumably provides advantages for behavioral thermo-osmoregulation and adjustment of ambient salinity as well as detection of olfactory clues needed for homing at shear zones (Westerberg, 1982). Tagging studies conducted during the adult migratory stage have revealed rapid transitions from saline to fresh waters and tolerance for substantial, brief changes in salinity among salmonids (Potter, 1988; Olson and Quinn, 1993).

Some Chinook salmon populations migrate upriver during the highest temperatures in, for example, the Sacramento (Alabaster, 1989), Columbia (Keefer et al., 2015; Keefer et al., 2018), and Fraser (Waples et al., 1990) River systems, although other populations in these large rivers migrate later or earlier. In contrast, coastal populations of sockeye salmon in systems subject to high temperatures (mean: $19^{\circ} \mathrm{C}$ ) tend to migrate prior to peak temperatures (Hodgson and Quinn, 2002). This pattern, combined with the more southerly distribution of Chinook salmon compared with that of sockeye salmon, indicates substantially greater thermal tolerance in Chinook salmon, as part of the suite of adaptations of salmonids to stressful or lethal effects of warm temperatures along migration routes (Crozier et al., 2008). However, population-specific variation in thermal tolerance has been documented in sockeye salmon (Eliason et al., 2011) and likely plays an important role in Chinook salmon as well.

Individual Chinook salmon use a variety of behavioral adaptations to high temperatures in rivers, such as delaying migration until temperatures decline, migrating at greater depths, and utilizing cool water refuges (Berman and Quinn, 1991; Strange, 2013; Keefer and Caudill, 2016). The Lake Washington Chinook salmon migrated near the annual peak temperatures, but individuals delayed in the estuary, occupied refuges in the estuary and lake, and moved vertically during migrations in those refuges. Because most Chinook salmon entering fresh water in late summer are near sexual maturity, a long delay in migration at high temperatures may result in lost reproductive opportunity. In contrast, the timing of steelhead and some early arriving sockeye salmon populations is more flexible before spawning, where they may delay, seeking cool water refuge sites when temperatures are stressful (Keefer et al., 2009; Mathes et al., 2010). Individual sockeye salmon may be less adaptable in their response to temperatures, instead relying on evolved traits such as earlier migration timing and use of vertical stratification in lakes (Hodgson and Quinn, 2002; Hinch et al., 2012). The Lake Washington sockeye salmon, studied by Newell and Quinn (2005) using methods similar to our study, displayed both responses, entering prior to peak temperatures, migrating rapidly through the ship canal, and residing for extended periods below the thermocline in the lake. Entry into fresh water prior to peak temperatures, as observed in the Lake Washington sockeye salmon, is an example of so-called premature migration, a pattern widely distributed in salmonids (Quinn et al., 2016). In some species and populations, this pattern is related to thermal conditions, although other factors are also important. The use of cool water below the thermocline in the lake by sockeye salmon starkly contrasts the vertical distribution, hence thermal experience, of Chinook salmon in the Lake Washington basin.

Exposure to warm water temperatures and the accumulation of DD have been correlated with prespawning mortality (Crossin et al., 2008; Keefer et al., 2009; Eliason et al., 2011), which can reach $90 \%$ for Chinook salmon in the upper reaches of the Willamette River (Keefer et al., 2015). Temperatures outside the acceptable range of $14-20^{\circ} \mathrm{C}$ for Chinook salmon can deplete energy that could have been used for migration, reproduction, and immune responses (Richter and Kolmes, 2005; McCullough et al., 2001; McCullough et al., 2009). The Lake Washington Chinook salmon accumulated 350-1050 DD, with most having between 500 and 750 DD, compared with 700-900 DD (maximum: 1500 DD) for those in the Willamette River (Keefer et al., 2015). Lake Washington has gotten warmer in the summer and fall over the past 5 decades (Fig. 2), and in the future the watershed is expected to see greater increases in temperature than any watershed in Puget Sound (Mantua et al., 2010). How Chinook salmon will respond to this marked change in water temperatures is of concern, in part because this population is part of an evolutionarily significant unit listed as threatened under the U. S. Endangered Species Act (Federal Register, 1999). Responses to warm water may include genetic and phenotypic changes in migration timing to avoid peak temperatures or more extensive behavioral thermoregulation. Of ultimate concern is how warming will affect the persistence of the salmon populations. The temperatures at the upper estuary in most summer months already approach or exceed levels associated with disease and energy depletion in migrating salmon; therefore, en route or prespawning mortality may result from further increases (McCullough et al., 2001; Crossin et al., 2008). Cool, hypolimnetic water will remain in Lake Washington if salmon can migrate successfully from the locks through the ship canal. In the future, temperatures could delay their migration or further stress them prior to reaching the lake. Therefore, if water temperatures in Lake Washington continue to rise, the success of migration and spawning by Chinook and sockeye salmon will likely be compromised.

\section{Acknowledgments}

We thank D. Seiler (WDFW) and K. Fresh (National Marine Fisheries Service) for their support in collaborative 
studies of Chinook and sockeye salmon at the locks; J. Newell for providing the sockeye salmon data used in this study; and E. Jeanes and C. Morello (R2), K. Kiyohara and P. Topping (WDFW), and B. Footen (Muckleshoot Indian Tribe) for their assistance with fish capture, tagging, and collection of telemetry and water-quality data. We especially acknowledge C. Ebel, who guided the protection of salmon at the locks over his length of service with the U.S. Army Corp of Engineers.

\section{Literature cited}

Alabaster, J. S.

1989. The dissolved oxygen and temperature requirements of king salmon, Oncorhynchus tshawytscha, in the San Joaquin Delta, California. J. Fish Biol. 34:331-332. Crossref

Berman, C. H., and T. P. Quinn.

1991. Behavioural thermoregulation and homing by spring Chinook salmon, Oncorhynchus tshawytscha (Walbaum), in the Yakima River. J. Fish Biol. 39:301-312. Crossref

Brawn, V. M.

1982. Behavior of Atlantic salmon (Salmo salar) during suspended migration in an estuary, Sheet Harbor, Nova Scotia, observed visually and by ultrasonic tracking. Can. J. Fish. Aquat. Sci. 39:248-256. Crossref

Brett, J. R.

1971. Energetic responses of salmon to temperature. A study of some thermal relations in the physiology and freshwater ecology of sockeye salmon (Oncorhynchus nerka). Am. Zool. 11:99-113.

Candy, J. R., E. W. Carter, T. P. Quinn, and B. R. Riddell. 1996. Adult Chinook salmon behavior and survival after catch and release from purse-seine vessels in Johnstone Strait, British Columbia. North Am. J. Fish. Manage. 16:521-529. Crossref

Connor, W. P., K. F. Tiffan, J. A. Chandler, D. W. Rondorf, B. D.

Arnsberg, and K. C. Anderson.

2019. Upstream migration and spawning success of Chinook salmon in a highly developed, seasonally warm river system. Rev. Fish. Sci. Aquac. 27:1-50. Crossref

Cooke, S. J., C. G. Hinch, G. T. Crossin, D. A. Patterson, K. K. English, M. C. Healey, J. S. Macdonald, J. M. Shrimpton, J. L. Young, A. Lister, et al.

2008. Physiological correlates of coastal arrival and river entry timing in later summer Fraser River sockeye salmon (Oncorhynchus nerka). Behav. Ecol. 19:747-758. Crossref

Crossin, G. T., S. G. Hinch, S. J. Cooke, D. W. Welch, A. G. Lotto,

D. A. Patterson, S. R. M. Jones, R. A. Leggeatt, M. T. Mathes,

J. M. Shrimpton, et al.

2008. Exposure to high temperature influences the behaviour, physiology, and survival of sockeye salmon during spawning migration. Can. J. Zool. 86:127-140. Crossref

Crozier, L. G., A. P. Hendry, P. W. Lawson, T. P. Quinn, N. J. Mantua, J. Battin, R. G. Shaw, and R. B. Huey.

2008. Potential responses to climate change in organisms with complex life histories: evolution and plasticity in Pacific salmon. Evol. Appl. 1:252-270. Crossref

Donaldson, M. R., S. G. Hinch, D. A. Patterson, J. Hills, J. O.

Thomas, S. J. Cooke, G. D. Raby, L. A. Thompson, D. Robichaud,

K. K. English, et al.

2011. The consequences of angling, beach seining, and confinement on the physiology, post-release behaviour and survival of adult sockeye salmon during upriver migration. Fish. Res. 108:133-141. Crossref
Døving, K. B., H. Westerberg, and P. B. Johnsen.

1985. Role of olfaction in the behavioral and neuronal responses of Atlantic salmon, Salmo salar, to hydrographic stratification. Can. J. Fish. Aquat. Sci. 42:1658-1667. Crossref

Drenner, S. M., T. D. Clark, C. K. Whitney, E. G. Martins, S. J. Cooke, and S. G. Hinch.

2012. A synthesis of tagging studies examining the behaviour and survival of anadromous salmonids in marine environments. PLoS ONE 7(3):e31311. Crossref

Durkin, J. T., and D. L. Park.

1967. A purse seine for sampling juvenile salmonids. Prog. Fish-Cult. 29:56-59. Crossref

Eliason, E. J., T. D. Clark, M. J. Hague, L. M. Hanson, Z. S. Gallagher, K. M. Jeffries, M. K. Gale, D. A. Patterson, S. G. Hinch, and A. P. Farrell.

2011. Differences in thermal tolerance among sockeye salmon populations. Science 332:109-112. Crossref

Emmett, E., R. Llansó, J. Newton, R. Thom, M. Hornberger, C. Morgan, C. Levings, A. Copping, and P. Fishman.

2000. Geographic signatures of North American west coast estuaries. Estuaries 23:765-792. Crossref

Federal Register.

1999. Endangered and threatened species; threatened status for three Chinook salmon evolutionarily significant units (ESUs) in Washington and Oregon, and endangered status for one Chinook Salmon ESU in Washington. Fed. Regist. 64:14308-14328. [Available from website.]

Fenkes, M., H. A. Shiels, J. L. Fitzpatrick, and R. L. Nudds.

2016. The potential impacts of migratory difficulty, including warmer waters and altered flow conditions, on the reproductive success of salmonid fishes. Comp. Biochem. Physiol. A 193:11-21. Crossref

Fujioka, J. T.

1970. Possible effects of low dissolved oxygen content in the Duwamish River estuary on migrating Chinook salmon. M.S. thesis, 77 p. Univ. Wash., Seattle, WA.

Gilhousen, P.

1990. Prespawning mortalities of sockeye salmon in the Fraser River system and possible causal factors. Int. Pac. Salm. Fish. Comm., Bull. 26, 52 p.

Goetz, F. A.

2016. Migration and residence patterns of salmonids in Puget Sound, Washington. Ph.D. diss., 187 p. Univ. Wash., Seattle, WA. [Available from website.]

Goniea, T. M., M. L. Keefer, T. D. Bjornn, C. A. Peery, D. H. Bennett, and L. C. Stuehrenberg.

2006. Behavioral thermoregulation and slowed migration by adult fall Chinook salmon in response to high Columbia River water temperatures. Trans. Am. Fish. Soc. 135:408419. Crossref

Hallock, R. J., R. F. Elwell, and D. H. Fry Jr.

1970. Migrations of adult king salmon Oncorhynchus tshawytscha in the San Joaquin Delta as demonstrated by the use of sonic tags. Calif. Dep. Fish Game, Fish Bull. 151:1-79.

Hasler, C. T., S. J. Cooke, S. G. Hinch, E. Guimond, M. R. Donaldson, B. Mossop, and D. A. Patterson.

2012. Thermal biology and bioenergetics of different upriver migration strategies in a stock of summer-run Chinook salmon. J. Therm. Biol. 37:265-272. Crossref

Hinch, S. G., S. J. Cooke, A. P. Farrell, K. M. Miller, M. Lapointe, and D. A. Patterson.

2012. Dead fish swimming: a review of research on the early migration and high premature mortality in adult Fraser River sockeye salmon Oncorhynchus nerka. J. Fish Biol. 81:576-599. Crossref 
Hodgson, S., and T. P. Quinn.

2002. The timing of adult sockeye salmon migration into fresh water: adaptations by populations to prevailing thermal regimes. Can. J. Zool. 80:542-555. Crossref

Holbrook, C. M., J. Zydlewski, D. Gorsky, S. L. Shepard, and M. T. Kinnison.

2009. Movements of prespawn adult Atlantic salmon near hydroelectric dams in the lower Penobscot River, Maine. North Am. J. Fish. Manage. 29:495-505. Crossref

Ishida, Y., A. Yano, M. Ban, and M. Ogura.

2001. Vertical movement of a chum salmon Oncorhynchus keta in the western North Pacific Ocean as determined by a depth-recording archival tag. Fish. Sci. 67:1030-1035.

Keefer, M. L., and C. C. Caudill.

2016. Estimating thermal exposure of adult summer steelhead and fall chinook salmon migrating in a warm impounded river. Ecol. Freshw. Fish. 25:599-611. Crossref

Keefer, M. L., C. A. Peery, and B. High.

2009. Behavioral thermoregulation and associated mortality trade-offs in migrating adult steelhead (Oncorhynchus mykiss): variability among sympatric populations. Can. J. Fish. Aquat. Sci. 66:1734-1747. Crossref

Keefer, M. L., T. S. Clabough, M. A. Jepson, J. P. Naughton, T. J. Blubaugh, D. C. Joosten, and C. C. Caudill.

2015. Thermal exposure of adult Chinook salmon in the Willamette River basin. J. Therm. Biol. 48:11-20. Crossref

Keefer, M. L., T. S. Clabough, M. A. Jepson, E. L. Johnson, C. A.

Peery, and C. C. Caudill.

2018. Thermal exposure of adult Chinook salmon and steelhead: diverse behavioral strategies in a large and warming river system. PLoS ONE 13(9):e0204274. Crossref

Kristinsson, K. Ó., G. Gudbergsson, and G. M. Gislason.

2015. Variable migration and delay in two stock components of an Atlantic salmon population. Environ. Biol. Fish. 98:1513-1523. Crossref

Ledgerwood, R. D., F. P. Thrower, and E. M. Dawley.

1991. Diel sampling of migratory juvenile salmonids in the Columbia River estuary. Fish. Bull. 89:69-78.

Lotze, H. K., H. S. Lenihan, B. J. Bourque, R. H. Bradbury, R. G. Cooke, M. C. Kay, S. M. Kidwell, M. X. Kirby, C. H. Peterson, and J. B. C. Jackson.

2006. Depletion, degradation, and recovery potential of estuaries and coastal seas. Science 312:1806-1809. Crossref

Magnuson, J. J.

2010. History and heroes: the thermal niche of fishes and long-term lake ice dynamics. J. Fish Biol. 77:1731-1744. Crossref

Mantua, N., I. Tohver, and A. Hamlet.

2010. Climate change impacts on streamflow extremes and summertime stream temperature and their possible consequences for freshwater salmon habitat in Washington State. Clim. Change 102:187-223. Crossref

Mathes, M. T., S. G. Hinch, S. J. Cooke, C. T. Crossin, D. A. Patterson, A. G. Lotto, and A. P. Farrell.

2010. Effect of water temperature, timing, physiological condition and lake thermal refugia on migrating adult Weaver Creek sockeye salmon (Oncorhynchus nerka). Can. J. Fish. Aquat. Sci. 67:70-84. Crossref

McDowall, R. M. 1988. Diadromy in fishes, 308 p. Timber Press, Portland, OR.

McCullough, D., S. Spalding, D. Sturdevant, and M. Hicks.

2001. Summary of technical literature examining the physiological effects of temperature on salmonids. U.S. Environ. Prot. Agency, Issue Pap. 5, EPA-910-D-01-005, 114 p.
McCullough, D. A., J. M. Bartholow, H. I. Jager, R. L. Beschta, M. L. Deas, and J. L. Ebersole.

2009. Research in thermal biology: burning questions for coldwater stream fishes. Rev. Fish. Sci. 17:90-115. Crossref

Minke-Martin, V., S. G. Hinch, D. C. Braun, N. J. Burnett, M. T. Casselman, E. J. Eliason, and C. T. Middleton.

2018. Physiological condition and migratory experience affect fitness-related outcomes in adult female sockeye salmon. Ecol. Freshw. Fish 27:296-309. Crossref

Moore, A., B. Bendall, J. Barry, C. Waring, N. Crooks, and L. Crooks.

2012. River temperature and adult anadromous Atlantic salmon, Salmo salar, and brown trout, Salmo trutta. Fish. Manage. Ecol. 19:518-526. Crossref

Newell, J. C., and T. P. Quinn.

2005. Behavioral thermoregulation by maturing sockeye salmon (Oncorhynchus nerka) in a stratified lake prior to spawning. Can. J. Zool. 83:1232-1239. Crossref

Nichols, F. H., J. E. Cloern, S. N. Luoma, and D. H. Peterson.

1986. The modification of an estuary. Science 231:567-573. Crossref

Olson, A. F., and T. P. Quinn.

1993. Vertical and horizontal movements of adult Chinook salmon, Oncorhynchus tshawytscha, in the Columbia River estuary. Fish. Bull. 91:171-178.

Potter, E. C. E.

1988. Movements of Atlantic salmon, Salmo salar L., in an estuary in south-west England. J. Fish Biol. 33 (Suppl. A): 153-159. Crossref

Quinn, T. P.

2018. The behavior and ecology of Pacific salmon and trout, $2^{\text {nd }}$ ed., 378 p. Univ. Wash. Press, Seattle, WA.

Quinn, T. P., B. A. Terhart, and C. Groot.

1989. Migratory orientation and vertical movements of homing adult sockeye salmon, Oncorhynchus nerka, in coastal waters. Anim. Behav. 37:587-599. Crossref

Quinn, T. P., J. A. Peterson, V. Gallucci, W. K. Hershberger, and E. L. Brannon.

2002. Artificial selection and environmental change: countervailing factors affecting the timing of spawning by coho and Chinook salmon. Trans. Am. Fish. Soc. 131:591-598. Crossref

Quinn, T. P., P. McGinnity, and T. E. Reed.

2016. The paradox of 'premature migration' by adult anadromous salmonid fishes: patterns and hypotheses. Can. J. Fish. Aquat. Sci. 73:1015-1030. Crossref

Raby, G. D., M. R. Donaldson, S. G. Hinch, T. D. Clark, E. J. Eliason, K. M. Jeffries, K. V. Cook, A. Teffer, A. L. Bass, K. M. Miller, et al.

2015. Fishing for effective conservation: context and biotic variation are keys to understanding the survival of Pacific salmon after catch-and-release. Integr. Comp. Biol. 55:554576. Crossref

Richter, A., and S. A. Kolmes.

2005. Maximum temperature limits for Chinook, coho, and chum salmon, and steelhead trout in the Pacific Northwest. Rev. Fish. Sci. 13:23-49. Crossref

Roscoe, D. W., S. G. Hinch, S. J. Cooke, and D. A. Patterson.

2010. Behaviour and thermal experience of adult sockeye salmon migrating through stratified lakes near spawning grounds: the roles of reproductive and energetic states. Ecol. Freshw. Fish 19:51-62. Crossref

Ruggerone, G. T, T. P. Quinn, I. McGregor, and T. D. Wilkinson.

1990. Horizontal and vertical movements of maturing steelhead trout, Oncorhynchus mykiss, in Dean and Fisher channels, British Columbia. Can. J. Fish. Aquat. Sci. 47:1963-1969. Crossref 
Russell, I. C., A. Moore, S. Ives, L. T. Kell, M. J. Ives, and R. O. Stonehewer.

1998. The migratory behaviour of juvenile and adult salmonids in relation to an estuarine barrage. Hydrobiologia 371/372:321-334. Crossref

Smith, J. M., K. L. Fresh, A. N. Kagley, and T. P. Quinn.

2015. Ultrasonic telemetry reveals seasonal variation in depth distribution and diel vertical migrations of sub-adult Chinook and coho salmon in Puget Sound. Mar. Ecol. Prog. Ser. 532:227-242. Crossref

Strange, J. S.

2010. Upper thermal limits to migration in adult Chinook salmon: evidence from the Klamath River Basin. Trans. Am. Fish. Soc. 139:1091-1108. Crossref

2012. Migration strategies of adult Chinook salmon runs in response to diverse environmental conditions in the Klamath River Basin. Trans. Am. Fish. Soc. 141:1622-1636. Crossref

2013. Factors influencing the behavior and duration of residence of adult Chinook salmon in a stratified estuary. Environ. Biol. Fish. 96:225-243. Crossref

Tanaka, H., Y. Takagi, and Y. Naito.

2000. Behavioral thermoregulation of chum salmon during homing migration in coastal waters. J. Exp. Biol. 203:1825-1833.
Walker, R. V., K. W. Myers, N. D. Davis, K. W. Aydin, K. D. Friedland, H. R. Carlson, G. W. Boehlert, S. Urawa, Y. Ueno, and G. Anma.

2000. Diurnal variation in thermal environment experienced by salmonids in the North Pacific as indicated by data storage tags. Fish. Oceanogr. 9:171-186. Crossref

Waples, R. S., G. A. Winans, F. M. Utter, and C. Mahnken.

1990. Genetic approaches to the management of Pacific salmon. Fisheries 15(5):19-25.

Westerberg, $\mathrm{H}$.

1982. Ultrasonic tracking of Atlantic salmon (Salmo salar L.)-II. Swimming depth and temperature stratification. Inst. Freshw. Resear. Drottningholm 60:102-120.

Williamson, C. E., J. E. Saros, W. F. Vincent, and J. P Smol. 2009. Lakes and reservoirs as sentinels, integrators, and regulators of climate change. Limnol. Oceanogr. 54:32732282. Crossref

Winder, W., and D. E. Schindler.

2004. Climate change uncouples trophic interactions in an aquatic ecosystem. Ecology 85:2100-2106. Crossref

Yates, D., H. Galbraith, D. Purkey, A. Huber-Lee, J. Sieber, J. West,

S. Herrod-Julius, and B. Joyce.

2008. Climate warming, water storage, and Chinook salmon in California's Sacramento Valley. Clim. Change 91:335-350. Crossref 